\title{
E-portfolio Formative and Summative Assessment: Reflections and Lessons Learned
}

\author{
John P. Egan \\ The University of British Columbia, \\ Vancouver, BC, Canada \\ john.egan@ubc.ca
}

\begin{abstract}
This paper describes how an e-portfolio strategy was developed for an online applications course in UBC's Master of Learning technology program. The overall assessment strategy for the course, both formative and summative, tool selection, and how e-portfolios were operationalized in the course are detailed. Lessons learned are also included.
\end{abstract}

Keywords: e-portfolio, portfolio, online, assessment.

\section{Introduction}

ETEC 565A is an online post-graduate course that provides several theoretical frameworks to assist educational professionals develop competencies related to the evaluation, selection and deployment of various learning technologies. Students gain hands-on experience with a range of learning technologies: web-publication, learning management systems, communication tools, community and collaboration tools, and social software tools. Each student completes a sequence of small assignments all designed support student learning in online, blended or face-to-face learning environments. ETEC565A is an elective offering in the University of British Columbia's wholly online Master of Learning technology (MET).

The MET program has been in operation since 2002. Over that time 175 educational and technological professionals have completed the MET, studying on either a full-time or part-time basis. Educational professionals working at the primary, secondary and tertiary levels; in workplace learning; educational designers; and non-profit managers have enrolled. Currently there are students enrolled based in Canada, the United States, Asia, Latin America, Europe and the Caribbean. From its inception, the MET's emphasis has been on informed, critical analysis of the implementation of technology in learning environments.

Our approach in ETEC 565A has been informed by a number of pedagogical principles. In an applications course it's easy to focus on learning how to deploy technology rather than how to

Material published as part of this publication, either on-line or in print, is copyrighted by the Informing Science Institute. Permission to make digital or paper copy of part or all of these works for personal or classroom use is granted without fee provided that the copies are not made or distributed for profit or commercial advantage AND that copies 1) bear this notice in full and 2) give the full citation on the first page. It is permissible to abstract these works so long as credit is given. To copy in all other cases or to republish or to post on a server or to redistribute to lists requires specific permission and payment of a fee. Contact Publisher@InformingScience.org to request redistribution permission. effectively and purposeful implement learning technologies in order to achieve goals and objectives. However, learning the "how to" is important: educational professionals unable to confidently use new technologies simply will not try. Thus our approach combines several pedagogical principles, including constructivism, competency-based educa- 
tion, collaborative learning, and self-directed learning.

Competency-based education in particular is an important aspect of the course's design. According to Epstein and Hundart, competency-based education is "the habitual and judicious use of communication, knowledge, technical skills, ... reasoning, emotions, values, and reflection in daily practice for the benefit of the individual and community being served" (2002, p. 27). For ETEC 565A the core competencies included proposal writing, instructional design, and web design. Rather than picking an arbitrary number of assignments for students to complete, we first looked at the core competencies identified in the early course planning process and brainstormed learning activities through they could be achieved.

This paper describes the development of an assessment e-portfolio strategy for students in a wholly online post-graduate educational technology program. According to Michelson and Mandell, a student portfolio aggregates "what is learned in the classroom.... and as a means of articulating and evidencing the prior, often experiential learning of a skilled and knowledgeable adult" (2004, p. 1). Bringing this concept into the digital realm, an e-portfolio allows students to "collect and organize the contents (of their portfolio) is many formats, including audio, video, graphical and text" (Seldin, 2004, p.19).

\section{Literature Review}

There is evidence that portfolio assessment (and e-portfolio assessment in particular) is rigorous and reliable (Chang, 2001) if operationalized correctly, as well as rewarding for studentsparticularly in university professional programs such as education. Davis, et al (2001) describe the benefits of using portfolio assessment in medical students' final examinations. Mason, Pegler and Weller (2004) demonstrate this in an post-graduate online Institute of Educational Technology course at the UK's Open University. Lynch and Punawarman (2004) showed in their analysis of assessment-focused e-portfolios the importance of clear assessment criteria to ensure reliability. Gülbahar and Tinmaz's (2006) pilot study of using an assessment e-portfolio in their software course found that timely feedback to students was important.

\section{Five Summatively Assessed E-Portfolio Assignments}

We set a goal for ourselves that assignments should, wherever possible, either draw on students' experiences, and, ideally, be transferable to their work contexts. Equally important, we developed assignments for the course that are a suite of interrelated, sequentially logical learning activities. We also wanted to structure the course (and its learning activities) in a way that more or less follows the arc of an educational development project plan.

Thus, in ETEC565A the e-portfolio is not merely a repository or aggregation point for student work: progression through the assignments is logical, purposeful and incremental. In completing their e-portfolios the students create a cohesive body of work that demonstrates breadth and depth of the subject matter. In the end we identified five assignments that would be summatively assessed, embedded across five course modules, as indicated in Table 1. 
Table 1: Summatively Assessed Assignments per Module

\begin{tabular}{|l|c|l|c|}
\hline Assignment & $\begin{array}{c}\text { Module } \\
\text { Number }\end{array}$ & Module Theme & $\begin{array}{c}\text { Value of } \\
\text { assignment }\end{array}$ \\
\hline LMS Proposal & 2 & $\begin{array}{l}\text { Presentation Tools: Spaces, Places and } \\
\text { Platforms for Learning }\end{array}$ & 15 \\
\hline LMS Quiz & 3 & Interaction and Assessment Tools & 15 \\
\hline Digital Story & 4 & Social Media & 20 \\
\hline LMS Course Site* & 5 & Multimedia & 25 \\
\hline Synthesis Reflection & 5 & & 15 \\
\hline
\end{tabular}

*Begun during Module 2

Each assignment has been designed so it is a manageable task within a timeframe of a few weeks, since the module within which each is embedded is two or three weeks in duration. Each is positioned within its corresponding module and represents a mini "capstone" assignment for that module. They are sequenced purposefully, in an order that reflects a common educational development (or project management) cycle.

The Proposal assignment requires students to construct a robust argument for selecting Moodle as their organization's learning management system (LMS). This assignment is written subsequent to the first course module (about core theoretical frameworks related to technology evaluation and selection) during the second module on learning platforms. In module two students have just finished a small group task developing an LMS evaluation rubric. As course authors we felt it important to be able to make a sound, detailed and concise "pitch" for new technology: a proposal to a key decision maker in their (or a fictive) organization.

In requiring students to create an online (Moodle) Quiz or Exam (with specific question types and assessment object attributes) we concomitantly require them to reflect upon formative and summative assessment's roles in teaching and learning. The different question types, configuring automated feedback, and embedding of media represent a comprehensive understanding of how LMSs can be used to support assessment. Students are also required to use genuine questions (and answers), with an aim that many will create something they can deploy in their own educational practice.

The Digital Story assignment has two key components. First, the students are introduced to the notions of web 2.0 and cloud computing: in fact, they must use a web 2.0 cloudbased tool to create and host their story. But they're also obligated to use a story--a narrative approach--in their own teaching. In requiring them to tell a story (rather than merely digitizing a lesson or lecture), many are looking at stories' pedagogical value for the first time.

While they start it relatively early in the course (roughly $30 \%$ of the way through), the LMS Course Site is viewed by many students as the technical capstone assignment of the course. They have already created two learning objects for their Moodle sites: a quiz and a digital story. They are also required to build out two complete learning modules largely populated with HTML content pages, program selective release and configure small group discussions. Perhaps most importantly, we require them to customize the default Moodle graphical user interface (GUI) to ease site navigation--to override the default design limitations of Moodle, in other words. 
Finally, a capstone Synthesis Reflection requires the students to look at their entire eportfolio and assess their own performance. Most students embrace the opportunity this assignment presents and look broadly and deeply at their overall experience.

These assignments were awarded between 15 and 20 points each for a total of 90 points, or 90 per cent of the student's course grade. The remaining 10 points are allocated based on course participation.

Students post these assignments on the corresponding page of their e-portfolios, which are all forward facing on the World Wide Web (though students can use a pseudonym if they are concerned about privacy). Each student's e-portfolio pages have identical names (proposal, course site, assessment, story, synthesis): any student can enter the URL for any colleague's corresponding page to compare assignments.

\section{Formative Assessment}

Summative assessment is important; in fact, students can be rather fixated on "marks"...to an extent where learning gets short shrift. However we also wanted to create mechanisms by which students could work as reflective practitioners in the course, outside of - above, to somesummative assessment. Imposing a rigid process of reflection seemed false--and unfair to those disinclined to journal. Our experience, however, convinced us that some semi-structured substantive reflection about the course, their expectations and their aspirations would be a strong predictor of student success.

Thus the first assignment students completed was a reflective Flight Path for the first page of their e-portfolios. Students had to review the course outline, assignment descriptions, and their own experiences to craft a preliminary "to do list" for themselves. While this was a required assignment, we decided to assess it qualitatively: anyone who substantively engages with the task "passes"; those who do not--a handful of students out of 200+--have to revise theirs. This allows me to give formative feedback very early on in the course.

Students are also encouraged to use the blogging "home" page of their e-portfolios for additional self-reflection. However, rather than impose an arbitrary quota for the number of blog entries, instead we include suggestions for possible entries at various points in the course. The area of the course from which most students draw their reflections is the self-directed eLearning toolkit. Each page of the toolkit has a practical exercise for exploring a technology: it also includes possible topics for blog reflections. Instructor presence on blog pages important-even brief notes to each entry to demonstrate you're reading.

\section{Operationalized}

One e-portfolio platform (UBC Blog's WordPress server) is used by all students--a decision significantly informed by both pragmatic and equity issues. A number of MET students come in with advance design skills, while others possess more rudimentary ones. The former are sometimes unhappy about being unable to use their own websites, weblogs, or servers for their eportfolios in ETEC 565A: they see our requirement to use UBC Blogs as a limitation on their creativity. Conversely, those with few (or no) design skills are often daunted, even discouraged, by the polish of their design professional colleagues' work. By using one e-portfolio platform the design and functionality "playing field" is significantly leveled: there is ample scope for customization of their e-portfolio sites at the theme level. But for those with less design experience, this platform allows them to create a polished, professional e-portfolio, and then incrementally improve it over time. 
In requiring all assignments to be completed using UBC's own platform (a customized installation of WordPressMU), we also avoid another frequent complication in an applications course: tool failure. In previous courses in the university's Bachelor of Education program, students using external tools - most commonly self-maintained external web servers - often were unable to complete work in a timely manner because of external tool failure. UBC's platforms are professionally maintained and backed up: when there is a disruption in service, the onus is on the institution to adjust student timelines or task requirements accordingly. Students have a choice of over twenty WordPress themes for their e-portfolios. Within many themes header images can be customized, CSS can be overridden, and many WordPress widgets can be activated.

We also leverage RSS extensively in the course. The instructor follows all students' blog entry feeds and uses an RSS reader to track assignment submission. Early in the course students in each course offering are also given an .opml aggregate RSS feed file for their learning community, along with set up instructions for using an RSS feed reader/aggregator both Windows and Mac OS X. This ensures students can focus on leveraging the platform, rather than wrestling with getting it to work. Summative feedback, however, is not delivered via the platform. First, we want to ensure students feel their confidentiality is respected when it comes to grades. As well, we leverage grading rubrics in our delivery LMS (currently WebCT Vista; soon to be Blackboard Learn 9). Something WordPressMU is not set up to do...yet.

\section{Conclusion}

From initially developing and implementing an e-portfolio-based assessment strategy for ETEC565A there have been several take-aways. First is that a process by which we identified a range of competencies that were subsequently organized as learning activities (mostly, but not entirely, summatively assessed ones). In sequence, the sum of whose was greater than its component parts

As well, the delivery platform selection is important. The right platform should be reliable, customizable, and well-maintained, which in the UBC context means using a centrally managed WordPressMU installation. Students should not need to wrestle to configure their e-portfolio sites: unambiguous set up instructions allow them to focus on the assignments rather than the setup. And leveraging features like RSS and comments adds interactivity to the e-portfolios, in terms of student-student and student-instructor interactions (Anderson, 2008). Student Evaluation of Teaching (SEoT) data indicates that instructor presence in the e-portfolio space inspires students to engage consistently with the reflective "blog" area of their sites.

Finally, rather than merely a digital repository, an e-portfolio whose contents represent a development process for the students is important. Sequencing of the assignments is important, as is distribution of the workload across the course's length.

\section{References}

Anderson, T. (2008). Towards a theory of online learning. In T. Anderson \& F. Elloumi, Theory and practice of online learning. Athabasca University.

Bates, A. W., \& Poole, G. (2003). Chapter 4: A framework for selecting and using technology. In Effective teaching with technology in higher education: foundations for success (pp. 77 - 105). San Francisco: Jossey Bass.

Chang, C. C. (2001). A study on the evaluation and effectiveness analysis of web-based learning portfolio (WBLP). British Journal of Learning technology, 32(4), 435-458.

Chickering, A. W., \& Gamson, Z. F. (1987). Seven principles for good practice in undergraduate education. American Association for Higher Education Bulletin, 39(7), 3-7. 
Chickering, A. W., \& Ehrmann, S. C. (1996). Implementing the seven principles: Technology as lever. American Association for Higher Education Bulletin, 49(2), 3-6.

Davis, M. H., Friedman Ben-David, M., Harden, R. M., Howie, P., Ker, J., McGhee, C., Pippard, M. J. \& Snadden, D. (2001). Portfolio assessment in medical students' final examinations. Medical Teacher, 23(4), 357-366.

Epstein, R. M., \& Hundart, F. M. (2002). Defining and assessing professional competence. Journal of the American Medical Association, 287, 226.

Gülbahar, Y., \& Tinmaz, H. (2006). Implementing project-based learning and e-portfolio assessment in an undergraduate course. Journal of Research on Technology in Education, 38(3), 309-327.

Lynch, L. L. \& Purnamwarman, P. (2004). Electronic portfolio assessments in US educational and instructional technology programs: Are they supporting teacher education? Tech Trends, 48(1), 50-56.

Mason, R., Pegler, C., \& Weller, M. (2004). E-portfolios: An assessment tool for online courses. British Journal of Learning technology, 35(6), 717-727.

McNiff, J., Lomax, P., \& Whitehead, J. (1996). You and your action research project. New York: Routledge.

Michelson, E., \& Mandell, A. (2004). Portfolio development and the assessment of prior learning. Sterling Virginia USA: Stylus Publishing.

Piaget, J. (1950). The psychology of intelligence. New York: Routledge.

Schmidt, H. G. (1983). Problem-based learning: Rationale and description. Medical Education, 17, 11-16.

Seldin, P. (2004). The teaching portfolio. Boston: Aker Publishing Company.

\section{Biography}

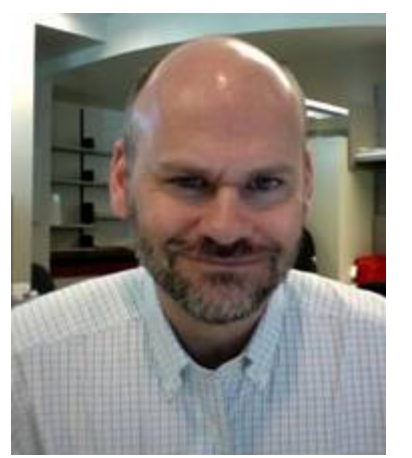

John P. Egan, $\mathrm{PhD}$ is the Senior Manager, Strategic Curriculum Services at CTLT, with many years' experience as a curriculum developer, instructor, facilitator, course designer, program administrator, and educational researcher. He has experience in the community, adult, corporate, private postsecondary and university-levels, in Canada and internationally. John has also been published widely in the fields of education and health. His work has been published in The Journal of Interprofessional Care, Studies in the Education of Adults, Convergence, and the Canadian Journal for the Study of Adult Education. 